\section{What is already known on this topic}

The associations between different types of fat and coronary heart disease do not seem to apply to stroke

Ecological data indicate that dietary fat intake is inversely related to risk of stroke

\section{What this study adds}

Intake of total fat, cholesterol, or major specific types of fat was not associated with risk of stroke

Consumptions of red meats, high fat dairy products, nuts, and eggs were also not appreciably related to risk of stroke

4 Willett WC, Sampson L, Stampfer MJ, Rosner B, Bain C, Witschi J, et al. Reproducibility and validity of a semiquantitative food frequency questionnaire. Am J Epidemiol 1985;122:51-65.

Walker AE, Robins M, Weinfeld FD. The national survey of stroke: clinical findings. Stroke 1981;12(2 pt 2 suppl 1):I13-44.

6 He K, Rimm EB, Merchant A, Rosner BA, Stampfer MJ, Willett WC, et al. Fish consumption and risk of stroke in men. JAMA 2002;288:3130-6.
7 Keys A, Anderson JT, Grande F. Serum cholesterol response to changes in the diet. I. Iodine value of dietary fat versus 2S-P. Metabolism $1965 \cdot 14: 747-58$

8 Ascherio A, Rimm EB, Giovannucci EL, Spiegelman D, Stampfer M, Willett WC. Dietary fat and risk of coronary heart disease in men: cohort follow up study in the United States. BMJ 1996;313:84-90.

9 Prospective Studies Collaboration. Cholesterol, diastolic blood pressure, and stroke: 13,000 strokes in 450,000 people in 45 prospective cohorts. Lancet 1995;346:1647-53.

10 Hebert PR, Gaziano JM, Hennekens CH. An overview of trials of cholesterol lowering and risk of stroke. Arch Intern Med 1995;155:50-5.

11 Heart Protection Study Collaborative Group. MRC/BHF heart protection study of cholesterol lowering with simvastatin in 20,536 highrisk individuals: a randomised placebo-controlled trial. Lancet 2002;360:7-22.

12 Keaney JF Jr, Vita JA. Atherosclerosis, oxidative stress, and antioxidant protection in endothelium-derived relaxing factor action. Prog Cardiovasc Dis 1995;38:129-54.

13 LaBiche R, Koziol D, Quinn TC, Gaydos C, Azhar S, Ketron G, et al. Presence of Chlamydia pneumoniae in human symptomatic and asymptomatic carotid atherosclerotic plaque. Stroke 2001;32:855-60.

14 Simon JA, Fong J, Bernert JT Jr, Browner WS. Serum fatty acids and the risk of stroke. Stroke 1995:26:778-89.

15 Iso H, Sato S, Umemura U, Kudo M, Koike K, Kitamura A, et al. Linoleic acid, other fatty acids, and the risk of stroke. Stroke 2002;33:2086-93.

16 Driss F, Vericel E, Lagarde M, Dechavanne M, Darcet P. Inhibition of platelet aggregation and thromboxane synthesis after intake of small amount of icosapentaenoic acid. Thromb Res 1984:36:389-96.

17 De Caterina R, Cybulsky MI, Clinton SK, Gimbrone MA Jr, Libby P. The omega-3 fatty acid docosahexaenoate reduces cytokine-induced expression of proatherogenic and proinflammatory proteins in human endothelial cells. Arterioscler Thromb 1994;14:1829-36.

(Accepted 18 July 2003)

\title{
Family attitudes to research using samples taken at coroner's postmortem examinations: review of records
}

Christopher Womack, Alison L Jack

The response of families asked for cadaveric blood and tissue may have been affected by adverse publicity about hospitals retaining tissues and organs removed at post mortem without consent. The tissue bank at Peterborough was asked to contribute control samples to an English Department of Health funded study to validate tests for viral markers in postmortem material. The study required samples of cadaveric blood (10-20 $\mathrm{ml}$ ), lymph node (one intrathoracic), and liver $\left(2 \mathrm{~cm}^{3}\right){ }^{1}$ Peterborough was selected because it does not have a high prevalence of bloodborne viral infections and because the tissue bank had the infrastructure to retrieve postmortem tissue for research. ${ }^{2}$ Participation in this study enabled us to evaluate the attitudes of families who were asked to allow the pathologist to take samples for research during a postmortem examination being done at the request of the coroner.

\section{Participants, methods, and results}

The coroner's officers identified deaths reported to the coroner that required postmortem examination and

Reasons for refusal among families asked by coroner's officers to take a telephone call from a research nurse

\begin{tabular}{lc} 
Reason for refusal & No of families $(\mathbf{n}=\mathbf{3 1})$ \\
\hline No reason given & 11 \\
\hline Family time pressures & 8 \\
\hline Family distressed/too upset & 6 \\
\hline Family/deceased against tissue donation & 5 \\
\hline Negative influence from media coverage & 1 \\
\hline
\end{tabular}

fulfilled the requirements of the viral markers study. ${ }^{1}$ The officers contacted families by telephone. After dealing with routine coroner's procedure, the officers asked the family members whether they were prepared to be contacted by a research nurse from Peterborough District Hospital. The officers explained that this would require a telephone interview of up to half an hour and that the research was being done to investigate tests for bloodborne viruses in relation to tissue transplantation. Reasons for refusal were recorded and sent to the research nurses.

The research nurses were given the name and contact number of family members willing to participate. The nurses then conducted the telephone interview according to the study protocol and notified the mortuary staff and pathologist if the family consented for retrieval of blood and tissue at the time of postmortem examination. The interview included lifestyle questions to allow researchers to determine risk factors for hepatitis and HIV if the viral marker tests gave positive results. Reasons for refusal were recorded.

Of 106 families asked to take a telephone call from a research nurse, 75 (71\%) agreed to do so. The table gives the reasons for refusal to participate. One family member admitted a negative influence from media coverage about organ and tissue retention and wanted the deceased to remain "whole." The interview was not completed in five cases (family not available in three cases, nurse unavailable in one, and interview terminated because of distress in one case). All those who completed the interview agreed to samples being taken.
See also Education and debate pp 802, 804

Department of Cellular Pathology, Peterborough District Hospital, Peterborough PE3 6DA

Christopher Womack consultant histopathologist Alison L Jack senior pathology liaison nurse

Correspondence to: C Womack chris.womack@ pbh-tr.nhs.uk

BMJ 2003;327:781-2 


\section{Comment}

Two thirds of families gave telephone consent to blood, lymph node, and liver samples being taken at postmortem examination and used as control samples in a study designed to validate tests for viral markers. The negative effect of media attention on postmortem retention of organ and tissues was small. The results compare with a $98.8 \%$ consent rate for use of surplus tissue in research among surgical patients from the same hospital trust. ${ }^{3}$ These findings reinforce the notion that attitudes about using tissue from dead people are different from those about tissue from the living.

The attitudes of recently bereaved families in our study are similar to those described in qualitative research published by the Retained Organs Commission. ${ }^{4}$ The commission's research found that most of the public support use of postmortem material for medical purposes and identified consent as an issue. A review from the NHS Centre for Reviews and Dissemination concludes that few data are suitable for inclusion in a systematic review of the psychological aspects of organ and tissue donation and suggests that primary research is a more suitable option. ${ }^{5}$

Funding: The viral markers study was funded by the Department of Health through the National Institute for Biological Standards and Controls.
Contributors: CW participated in the design of the study, collation of the results, and writing the report. ALJ did most of the interviews and participated in the design and collation of results. $\mathrm{CW}$ is the guarantor.

Competing interests: Peterborough Hospitals NHS Trust and commercial and academic clients stand to gain financially from research using human issue, although not from this study. CW is a member of the medical advisory board of Pathlore, which is responsible for processing tissue for the tissue bank and has done paid consultancy work for Capio, Pharmogene, Celltech, and Medical Solutions. CW and ALJ have received expenses and occasionaly fees for presentations and CW has received travel sponsorship to a meeting from GlaxoSmithKleine.

Ethical approval: The study was approved by Peterborough and Fenland local research ethics committee.

Padley DJ, Lucas SB, Saldanha J. Elimination of false negative HCV RNA results by removal of inhibitors in cadaver organ donor blood specimens. Transplantation 2003;76:432-4.

2 Womack C, Gray NM, Pearson JE, Fehily D. Cadaveric tissue supply to the commercial sector for research: collaboration between NHS pathology and NBS Tissue Services extending the options for donors. Cell Tissue Banking 2001:2:51-5.

Banking 2001;2:51-5.
Jack AL, Womack C. Why surgical patients do not donate tissue for commercial research: review of records. BMJ 2003;327:262.

Retained Organs Commission. Qualitative research to explore public perceptions regarding retention of organs and tissue for medical practice, teaching and research. www.nhs.uk/retainedorgans/trrep.pdf practice, teaching and

5 Forbes C, Glanville J, Kleijnen J. Psychological aspects of organ and tissue retention: a scoping review. www.doh.gov.uk/tissue/scopingreview.pdf (accessed 4 May 2003).

(Accepted 3 July 2003)

\section{British hospitals and different versions of the Glasgow coma scale: telephone survey}

Martin F Wiese

King's College Hospital, London SE5 9RS

Martin F Wiese specialist registrar in emergency medicine

Correspondence to: wiese@doctors.org.uk

BMJ 2003;327:782-3
The Glasgow coma scale is a clinical scoring system for objectively assessing how conscious a patient is. Although limited for predicting functional outcome, ${ }^{1}$ the scale is useful when making decisions about management in the acute setting, particularly for patients with traumatic brain injuries. Patients who score $<15$ need imaging or observation, and patients with scores $<9$ need to be promptly considered for definitive airways management.

The original Glasgow coma scale, published in 1974, had 14 points. ${ }^{2}$ Two years later, its authors introduced a distinction between "normal" and "abnormal" flexion (withdrawal to pain and decorticate response) increasing the "best motor response" item by one point. ${ }^{3}$ This revised scale is central to important clinical guidelines and has been the accepted version for more than 25 years. $^{4}$

Nevertheless, anecdotal evidence suggests that neurological observation charts based on the original 14 point scale are still being used in British hospitals. This study establishes the prevalence of this practice because it carries the potential for errors in communication and conflict with guidelines.

\section{Participants, methods, and results}

I conducted a national observational study of the neurological observation charts used in hospitals which care for adult patients with traumatic brain injuries.

Using the 2001-2 directory of the British Association for Accident and Emergency Medicine, I identified all UK emergency departments which manage patients with traumatic brain injuries. We contacted a sister or charge nurse in each departments. Using a structured telephone interview, we asked staff to determine which version of the Glasgow coma scale they used by checking the neurological observation chart visually. We also asked the nurse to name one ward providing observation for patients with traumatic brain injuries, where we repeated the interview. Finally, we telephoned one ward in every specialist neurosurgical unit in the United Kingdom (table).

\section{Comment}

The original, 14 point, Glasgow coma scale continues to be used in many British hospital units which manage patients with traumatic brain injuries. Many of the staff that we contacted were not aware that the version of the scale that they were using had been superseded.

The parallel use of two versions of the Glasgow coma scale in the United Kingdom has been virtually unnoticed, possibly because publication of the revised 